American J. of Engineering and Applied Sciences 3 (2): 342-349, 2010

ISSN 1941-7020

(C) 2010 Science Publications

\title{
Thermal Efficiency of a Combined Turbocharger Set with Gasoline Engine
}

\author{
Jarut Kunanoppadon \\ Department of Mechanical Engineering, \\ Faculty of Engineering and Industrial Technology, Silapakorn University, \\ Nakornprathom 73000, Thailand
}

\begin{abstract}
Problem statement: The technology of turbocharger has been used with internal combustion engines since 1905 to increase intake air pressure prior to putting it into the cylinders to increase thermal efficiency of the engine. Based on previous researches and uses of turbochargers, the pattern of turbocharger installation remains the same, either in series or in parallel. Therefore, this research aims to study installation of the combined turbocharger. The combined turbocharger set comprised two turbochargers of the same size having exhaust turbine connected in parallel to let both turbochargers work simultaneously and having intake air compressor connected in series for two stage compress. Approach: This research aimed to study the thermal efficiency of a combined turbocharger set with gasoline engine. The study was done by comparing the thermal efficiency between the combined turbocharger set and the parallel turbocharger set. The variation of both temperature and pressure of the intake air and exhaust gas were also investigated. The engine used in the study was TOYOTA engine model 1JZ-GTE with six cylinders and a total displacement volume of 2,491 cc. The engine was already installed with parallel turbocharger from the factory, therefore, the thermal efficiency test of the parallel turbocharger case was conducted first. Then, the engine was modified to be a combined turbocharger set and tested by the same procedure. The test was run under the speed of 2,000-5,000 rpm. Results: According to the test, the combined turbocharger set gave higher thermal efficiency than the parallel turbocharger set in all range of speed. At the speed of 2,500, 3,000, 3,500, $4,000,4,500$ and 5,000 rpm, the thermal efficiency of the combined turbocharger set was equal to 39.37, 57.73, 79.30, 67.66, 60.63 and 55.05\%, respectively. Meanwhile, the thermal efficiency of the parallel turbocharger set was equal to $15.40,22.61,44.96,55.21,56.38$ and 52.24\%, respectively. Conclusion: It could be seen that the thermal efficiency of the combined turbocharger set was higher than that of the parallel set by 2.55 times at the speed range of 2,500-3,000 rpm. The efficiency of the combined turbocharger would be equal or higher than that of the parallel set by 1.05 times at the speed of 5,000 rpm.
\end{abstract}

Key words: Combined turbocharger, thermal efficiency, gasoline engine

\section{INTRODUCTION}

The technology of turbocharger has been used with internal combustion engines since 1905 when Alfred Buechi initiated the idea of using turbocharger with big sized diesel engines such as boats. In 1920, a smaller sized turbocharger was used with airplanes of France and the US. Then, in 1923, a low-pressure turbocharger was invented to be used with both four-stroke and twostroke diesel engines, respectively (Summers, 2007). Turbocharger is used to increase intake air pressure prior to putting it into the cylinders to increase thermal efficiency of the engine. Turbocharger will use exhaust from the engine to drive the turbine before being released to the atmosphere. The product from the turbine will be transmitted via its shaft to the compressor to increase intake air pressure, which then will increase temperature of the intake air as well. The intake air with high pressure and temperature will flow through the intercooler to reduce the temperature and increase density before moving to the cylinders during the intake stroke. The intake air pressure as put by the turbocharger will be in line with the engine speed. Meanwhile, a wastegate will be installed to prevent the pressure not to be too high to damage the engine (Ferguson and Kirkpatrick, 2001). Figure 1 illustrates the diagram of single turbocharger installation.

Upon the use of single turbocharger, the size of the turbocharger corresponds to the total capacity of the cylinders of the engine. Large capacity of the cylinders 
of the engine will have large amount of intake air and exhaust, which hence will require a large size of turbocharger as well. Large sized turbocharger will have greater inertia compared to those of smaller sizes and will require more energy from exhaust to drive the turbine. Large turbocharger will be able to function if the engine speed is higher than small turbocharger; therefore, smaller turbochargers are installed together in parallel to make each of them operate at the same time (Heywood, 1998). Small sized turbochargers allow operation from the very low engine speed. The engine used in the study was model 1JZ-GTE of Toyota and has been installed with a parallel turbocharger set as illustrated in the diagram on Fig. 2. Another turbocharger installation type was to connect them in series (Heywood, 1998). Each turbocharger will alternatively function in different speed ranges or might support each other depending on the manufacturer. The installation of turbocharger in series is illustrated in Fig. 3.

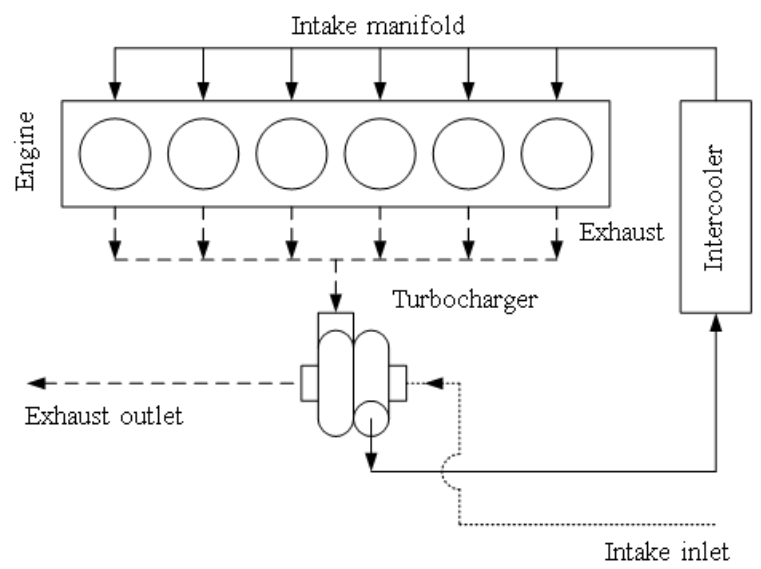

Fig. 1: Diagram of single turbocharger installation

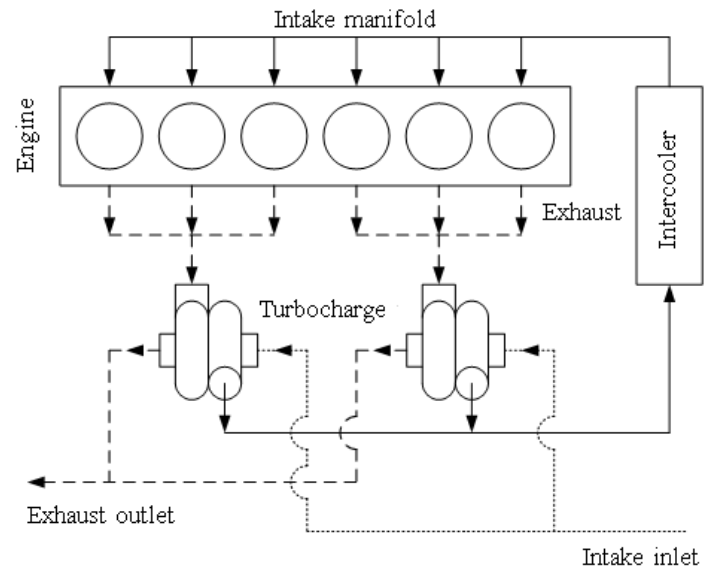

Fig. 2: Diagram of parallel turbocharger installation
At present, the processes to design and use turbochargers with engine are calculated by computers for more accuracy and convenience when it needs to change any parameters of turbochargers (Watson and Marzouk, 1977; Watson, 1981; Winterbone and Backhouse, 1986; Shan-Chin and Goyal, 1986; Schorn et al., 1987; Ramos, 1989; Payri et al., 1995; 2000; 2001; 2002; Benajes et al., 1996; 1997; 1998; 2000; Galindo et al., 2004). Nevertheless, actual tests with engine are still required to get correct results and find any errors made by calculation of computers (Galindo et al., 2006). Turbocharger technological research and development will be mostly about development of flowing fluid through the turbocharger such as variable diffuser vanes and variable inlet guide vanes (Jiao et al., 2009). Mohtar et al. (2008) had studied the use of variable inlet guide vanes towards the efficiency of compressor and the functioning time of the turbocharger. Helmet et al. (2004) had studied the inlet swirl generator device by using Computational Fluid Dynamics (CFD) and running tests to analyze its effects to the operational efficiency. The two researches give importance to improvement of intake air quality prior to entering the turbocharger, similar to the works of Uchida et al. (2006) and Galindo et al. (2007). Some turbocharger technological research and development works are related to physical improvement of the turbocharger. Ebisu et al. (2004) had studied and developed turbocharger in Variable Geometry (VG) as vane angles could be changed in line with engine speed while Matsumoto et al. (2008) had developed small turbochargers with high efficiency suitable to gasoline engines, which have high exhaust temperature.

Based on previous researches and uses of turbochargers, the pattern of turbocharger installation remains the same, either in series or in parallel.

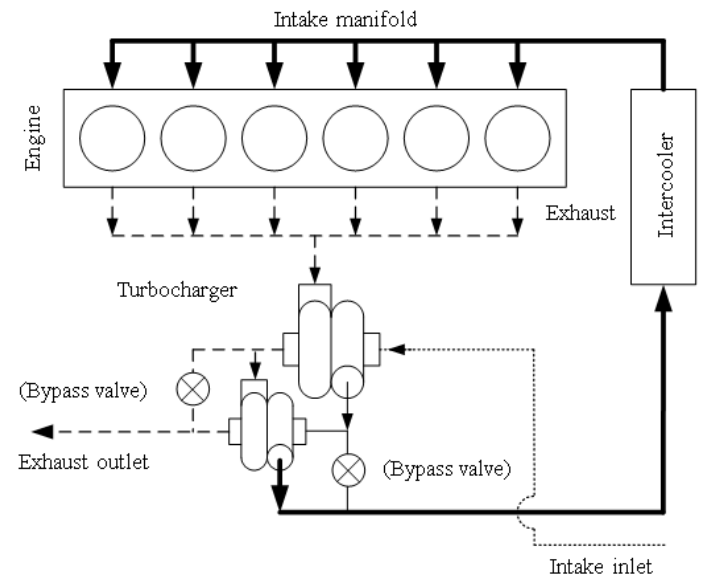

Fig. 3: Diagram of series turbocharger installation 


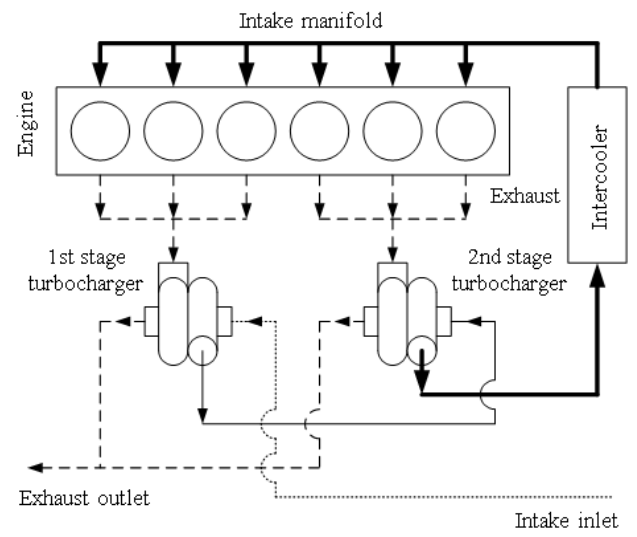

Fig. 4: Diagram of combined turbocharger installation

Therefore, this research aims to study installation of the combined turbocharger. Two turbochargers of the same size were installed by having exhaust turbine connected in parallel to let both turbochargers work simultaneously while having intake air compressor connected in series for two stage compressed. The installation diagram is illustrated in Fig. 4. Thermal efficiency was tested for both types of turbochargers. The results were compared under the hypothesis that two steps intake air of the combined turbocharger would give higher air pressure compared to the parallel one and thus would result in higher thermal efficiency.

\section{MATERIALS AND METHODS}

The research was divided into three parts: (1) to test thermal efficiency of the parallel turbocharger installed in the engine to be used as the reference, (2) to modify the turbocharger to become the combined one and test its thermal efficiency accordingly and (3) to analyze and compare the test results. The engine used in the study was the model 1JZ-GTE of Toyota with six cylinders and a total displacement volume of 2,491 cc. The bore is $86 \mathrm{~mm}$ and the stroke is $71.55 \mathrm{~mm}$. The compression ratio is 8.5 with the max power of $206 \mathrm{~kW}$ at 6,200 rpm and the max torque of $363 \mathrm{Nm}$ at 4,800 rpm. Two turbochargers of the model CT12A were installed in parallel from the factory.

Thermal efficiency test of the parallel turbocharger: Thermal efficiency of parallel turbocharger could be calculated from the thermal efficiency of a single turbocharger by setting the flow of intake air mass through the compressor to be equal to that of the exhaust through the turbine as illustrated in Eq. 1:

$$
\eta_{\text {th }}^{\mathrm{p}}=\frac{\mathrm{T}_{\mathrm{i}}^{\mathrm{c}}\left[\left(\mathrm{P}_{\mathrm{o}}^{\mathrm{c}} / \mathrm{P}_{\mathrm{i}}^{\mathrm{c}}\right)^{(\mathrm{k}-1) / \mathrm{k}}-1\right]}{\mathrm{T}_{\mathrm{i}}^{\mathrm{t}}\left[1-\left(\mathrm{P}_{\mathrm{o}}^{\mathrm{t}} / \mathrm{P}_{\mathrm{i}}^{\mathrm{t}}\right)^{(\mathrm{k}-1) / \mathrm{k}}\right]}
$$

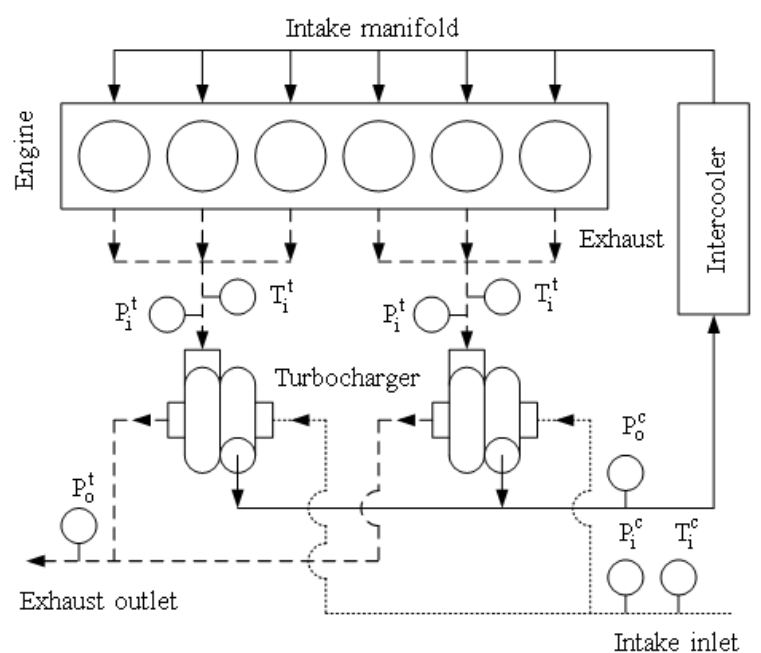

Fig. 5: The installation of thermocouples and pressure gauges for thermal efficiency test of parallel turbocharger

Based on the equation, thermal efficiency calculation requires temperature and pressure measured by equipment from many positions. The installation of thermocouples and pressure gauges is illustrated in Fig. 5. Thermocouples type $\mathrm{K}$ were used to measure temperature and Bourdon gauges were used to measure pressure. Temperature and pressure of intake air and exhaust were measured at four positions at the same time. The first position was to measure both temperature and pressure of intake air at the entrance of the compressor behind the air filter. The second position was to measure only temperature of intake air at the intake air manifold after exiting the compressor. The third position was to measure both temperature and pressure of the exhaust at the entrance of the turbine. The last position was to measure only temperature of the exhaust at the exhaust manifold after exiting the turbine.

The test was conducted by running the engine at the speed of 2,500 rpm until the temperature at the exit of the compressor was stable (Pulkrabek, 2004) before starting to collect data. Actual speed, temperature and pressure at each position were measured for three times to get the average figures. Then, the same tests were conducted with different engine speeds from 2,500$3,000,3,500,4,000,4,500$ and 5,000 rpm, respectively. After that, the speed would be reduced from 5,0004,500, 4,000, 3,500, 3,000 and 2,500 rpm, respectively. Therefore, the test would be conducted at 11 speeds each time and the test would be run for five times to get the average figures prior to using the average pressure and temperature for thermal efficiency of parallel turbocharger at different engine speeds. 


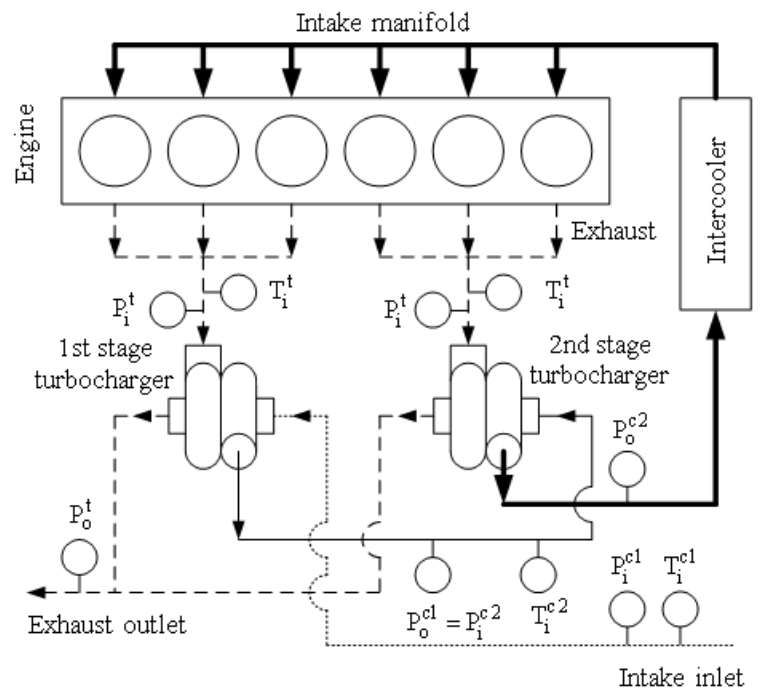

Fig. 6: The installation of thermocouples and pressure gauges for thermal efficiency test of combined turbocharger

Thermal efficiency test of the combined turbocharger: After conducting the tests for thermal efficiency of the parallel turbocharger, the pipes of intake air of the turbocharger were modified to make the turbocharger become a combined one. Thermal efficiency of the combined turbocharger could be calculated from thermal efficiency of the single turbocharger equation. Intake air mass flowing through the compressor would be equal to two times of the exhaust flowing through the turbine as shown in Eq. 2:

$$
\eta_{\text {th }}^{\mathrm{c}}=\frac{\mathrm{T}_{\mathrm{i}}^{\mathrm{c} 1}\left[\left(\mathrm{P}_{\mathrm{o}}^{\mathrm{c}} / \mathrm{P}_{\mathrm{i}}^{\mathrm{c} 1}\right)^{(\mathrm{k}-1) / \mathrm{k}}-1\right]+\mathrm{T}_{\mathrm{i}}^{\mathrm{c} 2}\left[\left(\mathrm{P}_{\mathrm{o}}^{\mathrm{c} 2} / \mathrm{P}_{\mathrm{i}}^{\mathrm{c} 2}\right)^{(\mathrm{k}-1) / \mathrm{k}}-1\right]}{\mathrm{T}_{\mathrm{i}}^{\mathrm{t}}\left[1-\left(\mathrm{P}_{\mathrm{o}}^{\mathrm{t}} / \mathrm{P}_{\mathrm{i}}^{\mathrm{t}}\right)^{(\mathrm{k}-1) / \mathrm{k}}\right]}
$$

From the equation, it can be seen that there were more positions to measure temperature and pressure than the parallel turbocharger. More thermocouples and pressure gauges hence were set up as illustrated in Fig. 6. The tests were conducted similar to the first step by running the engine 11 times at different speed for each test to collect data at the actual speed, temperature and pressure at different positions. The tests were run for five times to get the average figures prior to use in thermal efficiency calculation of the combined turbocharger at different speeds as illustrated in Fig. 7.

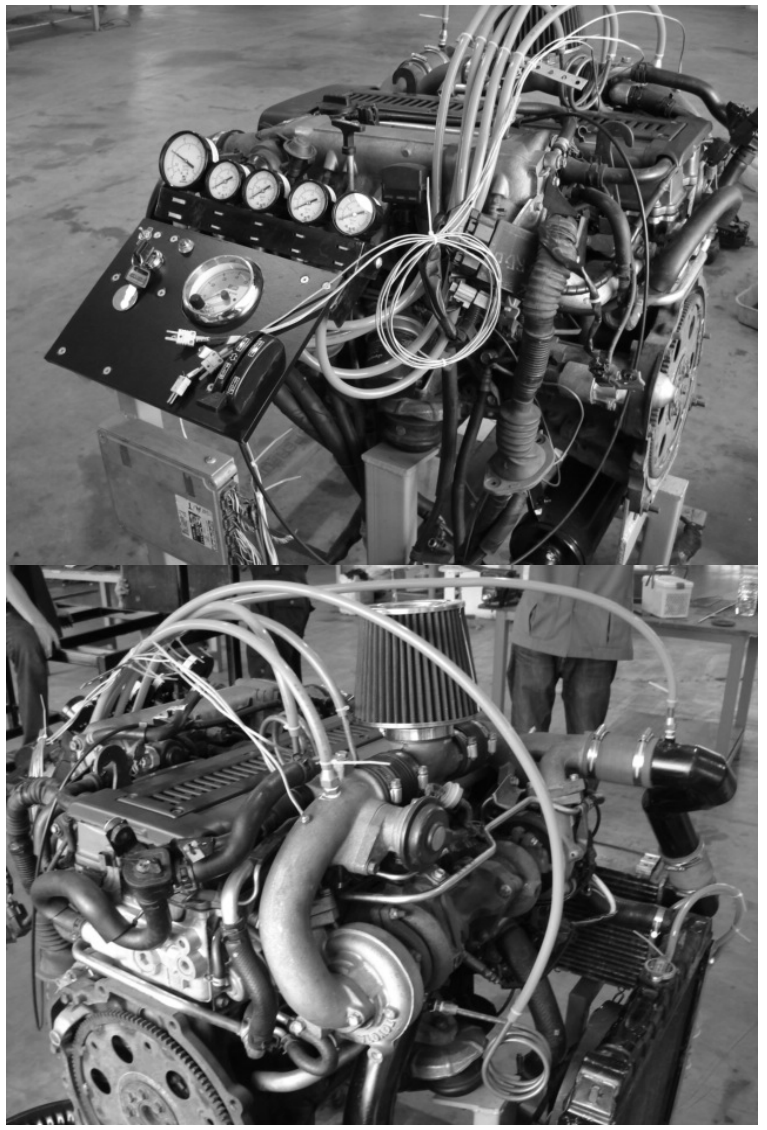

Fig. 7: Experimental setup

Analysis and comparisons of the tests: Data of temperature and pressure at different positions collected from different speeds of both types of turbochargers were compared and analyzed. Thermal efficiency of both sets of the turbochargers then were compared at different speeds and the ratio of thermal efficiency could be calculated from Eq. 3:

$\mathrm{r}_{\mathrm{th}}=\eta_{\mathrm{th}}^{\mathrm{c}} / \eta_{\mathrm{th}}^{\mathrm{p}}$

\section{RESULTS AND DISCUSSION}

Intake air pressure at the compressor: Intake air pressure at the compressor at different engine speeds of both combined and parallel turbochargers are illustrated in Fig. 8. For the parallel turbocharger, the intake air pressure at the entrance of the compressor (line a) was lower than the atmospheric one and would reduce as the engine speed increased due to greater attraction at about 101.32-100.00 kPa. After the intake air pressure was increased in parallel, the pressure at the exit of the compressor (line b) would increase slightly in the speed 
range of 2,000-2,500 rpm and would soar rapidly in the speed range of 2,500-4,000 rpm. However, the figure would be increasing in a slower rate in the speed range of 4,500-5,000 rpm at about 107.50-160.69 kPa. For the combined turbocharger, the intake air pressure at the entrance of the first compressor (line c) tended to be similar to that of the parallel turbocharger as the pressure would be lower than the atmospheric one and would reduce as the engine speed increased. After the intake air pressure was increased at the first compressor, the pressure at the exit of the first compressor (line d) would increase. In the speed range of 2,500-3,000 rpm, the pressure would be higher than that of the parallel turbocharger. However, the pressure of the combined turbocharger would be lower than that of the parallel one at the speed higher than 3,500 rpm. The maximum pressure was at $135.81 \mathrm{kPa}$ at the speed of 4,000 rpm. Lower engine speed would have higher compressing efficiency while high engine speed would reduce the efficiency since intake air mass flowing into each compressor in the combined turbocharger would be greater than that of the parallel one by about two times. However, compression in the combined turbocharger would be made in two steps. The intake air from the first compressor would be flowing to the second one, therefore, the intake air pressure after exiting the second compressor (line e) would be high even further. As illustrated in the picture, the pressure would rise rapidly in the speed range of 2,500-3,500 rpm and would remain constant at the speed of 3,500 rpm since the wastegate could function at this range of speed. The combined turbocharger could increase intake air pressure more than the parallel one in the tests at all ranges of speed. The figure was about 109.50-130.99 kPa.

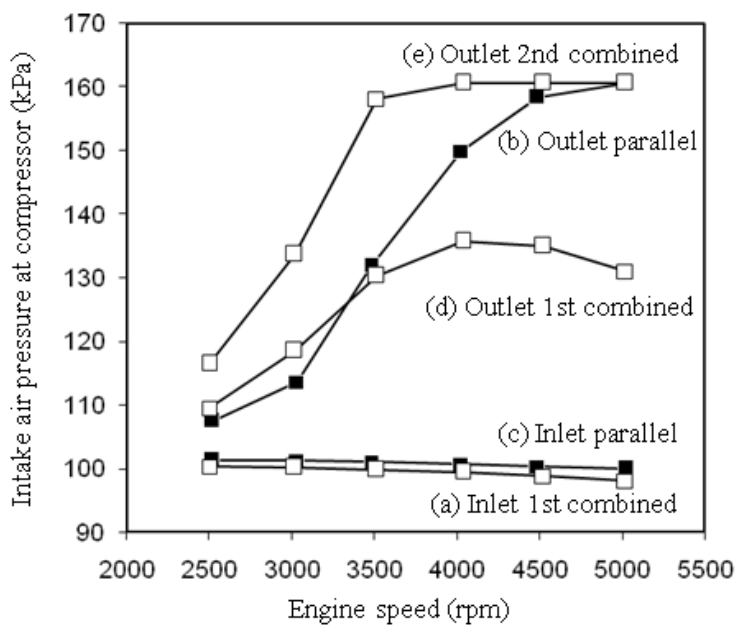

Fig. 8: Intake air pressure at the compressor
Intake air temperature at the compressor: Intake air temperature at the compressor at different speeds of both combined and parallel turbochargers are illustrated in Fig. 9. For the parallel turbocharger, the intake air temperature at the entrance of the compressor (line a) tended to increase as the engine speed increased because the heat flows from the engine to the atmosphere. The temperature was around 308.57$310.89 \mathrm{~K}$. For the combined turbocharger, the temperature at the entrance of the first compressor (line b) tended to be similar to that of the parallel turbocharger as they both were temperature of the outside air. The temperature tended to rise as the engine speed increased and the figure was around 309.60$311.93 \mathrm{~K}$, which was higher than that of the parallel turbocharger by average of $0.33 \%$ as the tests were conducted on different days. When the intake air pressure was increased at the first compressor, both pressure and temperature would be increased further before being compressed again. The temperature of the intake air at the entrance of the second compressor (line c) would increase at the engine speed of 2,500-4,500 rpm. The maximum temperature was $337.36 \mathrm{~K}$ at the engine speed of $4,500 \mathrm{rpm}$, but the figure declined as the engine speed increased.

Exhaust pressure at the turbine: Exhaust pressure at the turbine at different engine speeds of both combined and parallel turbochargers are illustrated in Fig. 10. For the parallel turbocharger, the exhaust pressure at the entrance of the turbine (line a) would increase as the engine speed increased and the pressure was about 438.80-641.47 kPa. After flowing through the turbine,

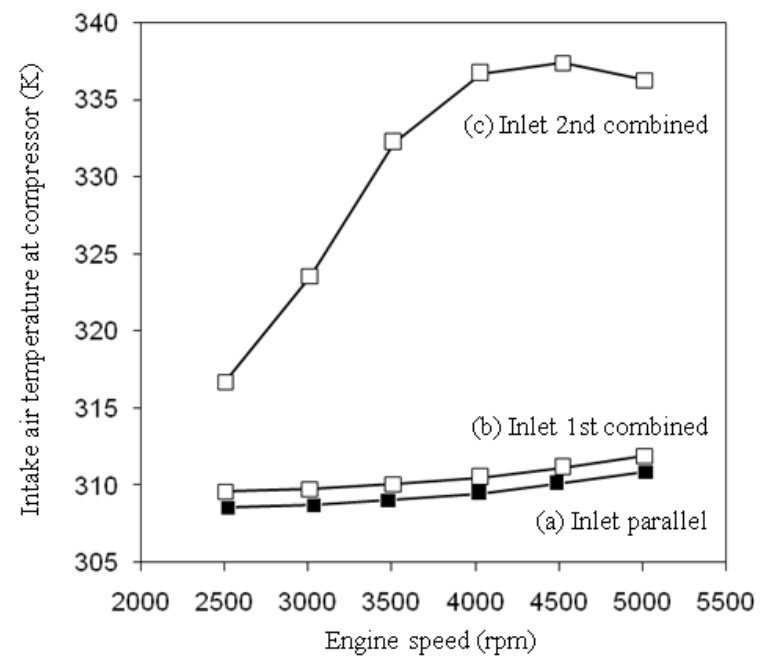

Fig. 9: Intake air temperature at the compressor 
Am. J. Engg. \& Applied Sci., 3 (2): 342-349, 2010

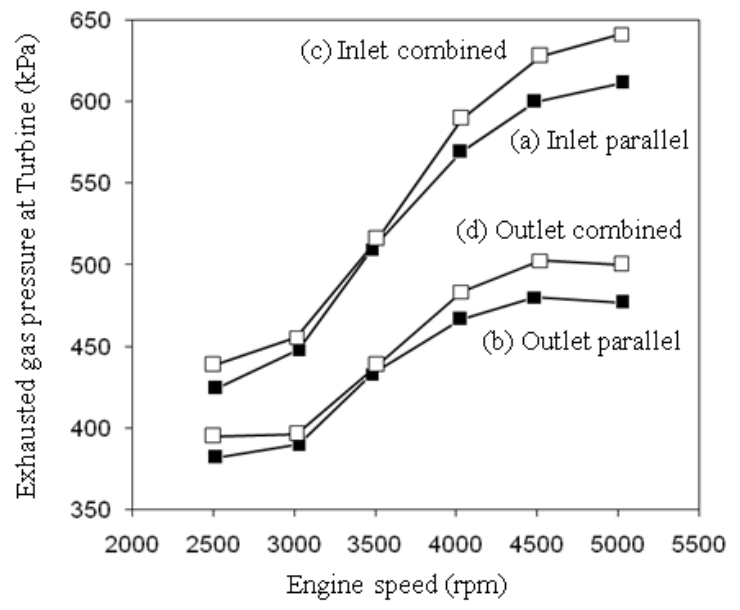

Fig. 10: Exhaust pressure at the turbine

the pressure at the exit of the turbine (line b) would reduce but tended to increase as the engine speed increased as well. The figure was about 382.05$480.12 \mathrm{kPa}$. For the combined turbocharger, the exhaust pressure at the entrance of the turbine (line c) and at the exit from the turbine (line d) tended to be similar to that of the parallel one. The figure would be higher than the parallel turbocharger in all ranges of engine speed tested since the combined turbocharger would have higher intake air pressure prior to entering the engine and the exhaust therefore would have higher pressure after combustion. The exhaust pressure at the entrance of the turbine was around 438.80-641.47 $\mathrm{kPa}$ while the exhaust pressure at the exit of the turbine was about 394.92-502.56 kPa.

Exhaust temperature at the turbine: Exhaust temperature at the turbine at different engine speeds of both combined and parallel turbochargers are illustrated in Figure 11. The exhaust temperature at the entrance of the turbine tended to be similar in both turbochargers. The temperature would increase as the engine speed increased. The exhaust temperature at the turbine of the combined turbocharger would be higher than that of the parallel one in all ranges of speed tested because the intake air temperature prior to entering the engine was higher. Exhaust temperature at the entrance of the turbine of the parallel turbocharger (line a) was about 1,149.96-1,245.87 $\mathrm{K}$ while the exhaust temperature at the entrance of the turbine of the combined turbocharger (line b) was about 1,157.19-1,248.38 K.

Thermal efficiency of turbocharger: Thermal efficiency of both combined and parallel turbochargers are illustrated in Fig. 12. For the parallel turbocharger,

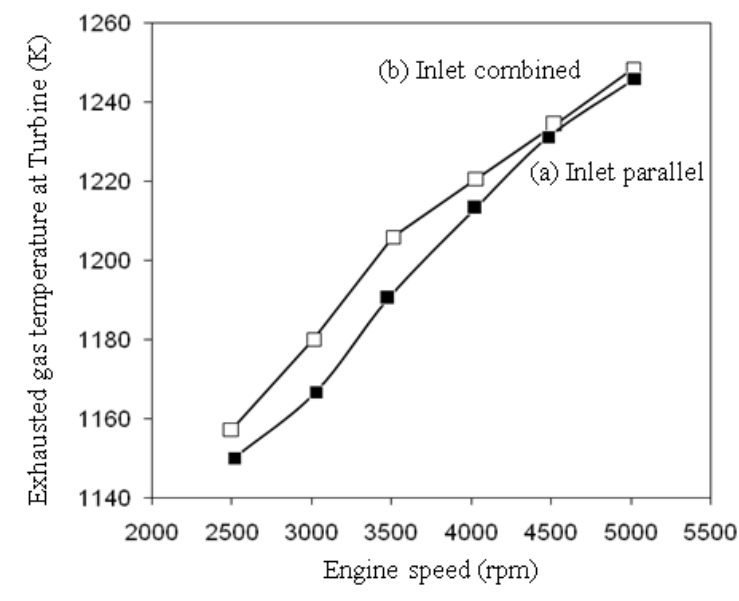

Fig. 11: Exhaust temperature at the turbine

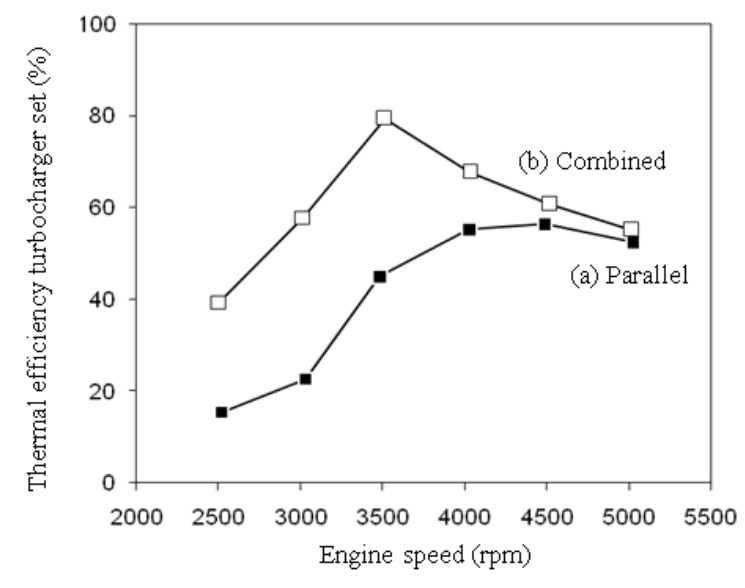

Fig. 12: Thermal efficiency of turbocharger

the thermal efficiency (line a) was at $15.40 \%$ at the engine speed of 2,500 rpm. The figure increased as the speed increased. The maximum efficiency was at $56.38 \%$ at the engine speed of $4,500 \mathrm{rpm}$. Then, the figure reduced to $52.34 \%$ at the engine speed of $5,000 \mathrm{rpm}$. For the combined turbocharger, the thermal efficiency (line b) was higher than that of the parallel one at all engine speeds in all rounds of test. The thermal efficiency was at $39.37 \%$ at the engine speed of 2,500 rpm. The figure increased as the speed increased. The maximum efficiency was at $79.30 \%$ at the engine speed of 3,500 rpm. Then, the figure reduced to $55.05 \%$ at the engine speed of 5,000 rpm. Considering the ratio of thermal efficiency as illustrated in Fig. 13, the ratio was equal to 2.556 at the engine speed of 3,000 rpm. The combined turbocharger therefore had higher thermal efficiency than that of the parallel one by 2.56 times. The ratio then reduced to 1.05 as the engine speed increased to 5,000 rpm. 
Am. J. Engg. \& Applied Sci., 3 (2): 342-349, 2010

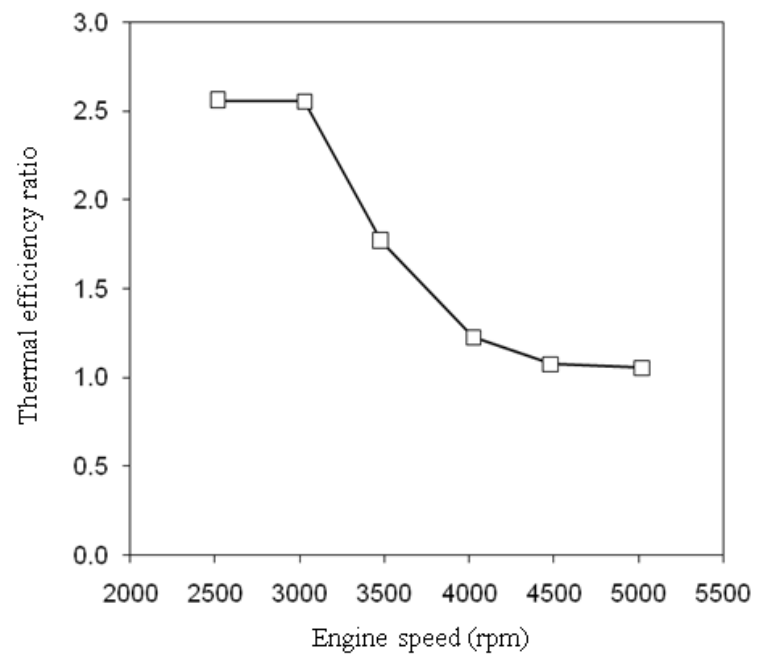

Fig. 13: Thermal efficiency ratio

\section{CONCLUSION}

Installing a combined turbocharger by connecting the compressor in series to increase intake air pressure and connecting the exhaust driving the turbine in parallel could increase the intake air pressure more than installing the turbocharger in the parallel manner as tested in all ranges of speed. The clear difference in pressure of about $18.84 \%$ could be seen in the range of speed of 2,500-3,000 rpm. The temperature of the intake air prior to entering the engine therefore was increased as well as the exhaust flowing out of the engine by the average of $0.69 \%$. The exhaust pressure exiting the engine was also increased by the average of $0.20 \%$ while the exhaust pressure after flowing through the turbine was increased by the average of $3.23 \%$. Installing turbocharger in the combined manner gave higher thermal efficiency than that of the parallel one in all ranges of speed tested. At the engine speed around 2,500-3,000 rpm, the thermal efficiency of the combined turbocharger was higher than that of the parallel one by 2.55 times. As the speed increased, the thermal efficiency of the combined turbocharger would be similar to the parallel one but the figure would be higher by 1.05 times at the engine speed of 5,000 rpm.

\section{ACKNOWLEDGEMENT}

Sincere gratitude will be given to the Department of Mechanical Engineering of Faculty of Engineering and Industrial Technology of Silpakorn University for supporting the funds for this research.

\section{REFERENCES}

Benajes, J., E. Reyes and J.M. Lujan, 1996. "Modeling study of the scavenging process in a turbocharged diesel engine with modified valve operation," Proc. IMechE Part C: J.Mech. Eng. Sci, ISSN: 02637154, vol. 210, pp. 383-393.

Benajes, J., E. Reyes, J. Galindo and J. Peidro, 1997. Predesign model for intake manifolds in internal combustion engines. SAE Paper 970055. http://www.sae.org/technical/papers/970055

Benajes, J., E. Reyes, V. Bermudez and J.R. Serrano, 1998. Pre-design criteria for exhaust manifolds in I.C. automotive engines. SAE Paper 980783.

Benajes, J., J.M. Lujan and J.R. Serrano, 2000. Predictive modeling study of the transient load response in a heavy-duty turbocharged diesel engine. SAE Paper 2000-01-0583.

Ebisu, M., Y. Terakawa and S. Ibaraki, 2004. Mitsubishi turbocharger for lower pollution cars Tech. $\quad$ Rev., 41: 40-41. https://www.mhi.co.jp/en/technology/review/abstra cte-41-1-40.html

Ferguson, C.R. and A.T. Kirkpatrick, 2001. Internal Combustion Engine Applied Thermo Sciences. 2nd Edn., John Wiley and Sons, ISBN: 0-471-35617-4, pp: 15-18.

Galindo, J., J.M. Lujan, J.R. Serrano, V. Dolz and S. Guilain, 2004. Design of an exhaust manifold to improve transient performance of a high-speed turbocharged diesel engine. Exp. Therm. Fluid Sci., 28: 863-875. DOI: 10.1016/j.expthermflusci.2004.01.003

Galindo, J., J.R. Serrano, C. Guardiola and C. Cervello, 2006. Surge limit definition in a specific test bench for the characterization of automotive turbochargers. Therm. Fluid Sci., 30: 449-462. DOI: 10.1016/j.expthermflusci.2005.06.002

Galindo, J., J.R. Serrano, X. Margot, A. Tiseira and N. Schorn et al., 2007. Potential of flow pre-swirl at the compressor inlet of automotive engine turbochargers to enlarge surge margin and overcome packaging limitations. Int. J. Heat Fluid Flow, 28: 374-387. DOI: 10.1016/j.ijheatfluidflow.2006.06.002

Heywood, J.B., 1998. Internal Combustion Engine Fundamentals. McGraw-Hill, ISBN: 0-07-1004998, pp: 248-255.

Jiao, K., H. Sun, X. Li, H. Wu and E. Krivitzky et al., 2009. Numerical simulation of air flow through turbocharger compressors with dual volute design. Applied Energy, 86: 2494-2506. DOI: 10.1016/j.apenergy.2009.02.019 
Matsumoto, K., Y. Jinnai, M. Tojo, N. Hayashi and S. Ibaraki, 2008. Development of compact and high-performance turbocharger for $1,050^{\circ} \mathrm{C}$ exhaust gas. Tech. Rev., 45: 1-5. https://www.mhi.co.jp/en/technology/review/abstra cte-45-3-1.html

Mohtar, H., P. Chesse, A. Yammine and J.F. Hetet, 2008. Variable inlet guide vanes in a turbocharger centrifugal compressor: Local and global study. SAE Paper 01-0301. http://www.sae.org/technical/papers/2008-01-0301

Payri, F., J. Benajes and J. Galindo, 1995. Onedimensional fluid-dynamic model for catalytic converters in automotive engines. SAE Paper 950785. http://www.sae.org/technical/papers/950785

Payri, F., E. Reyes and J.R. Serrano, 2000. A model for load transients of turbocharged diesel engines. 1999 SAE Trans. J. Eng., 108: 363-375.

Payri, F., E. Reyes and J. Galindo, 2001. Analysis and Modeling of the fluid dynamic effects in branched exhaust junctions of ICE. Int. J. Gas Turb. Power Trans. ASME., 123: 197-203. DOI: 10.1115/1.1339988

Payri, F., J. Benajes, J. Galindo and J.R. Serrano, 2002. Modeling of turbocharged diesel engines in transient operation. Part 2: wave action models for calculating the transient operation in a high speed direct injection engine. Proc. IMechE Part D., 216: 479-493. DOI: 10.1243/09544070260137507

Pulkrabek, W.W., 2004. Engineering Fundamentals of the Internal Combustion Engine. 2nd Edn., Person. Education, ISBN: 0-13-191855-9, pp: 226-231.
Ramos, J.I., 1989. Internal Combustion Engine Modeling. Hemisphere Publishing, ISBN: 0891161570, pp: 422.

Schorn, N., F. Pischinger and H. Schulte, 1987. Computer simulation of turbocharged diesel engines under transient conditions. SAE Paper 870723.

Shan-Chin, T., M.R. Goyal, 1986. Dynamic turbocharged diesel engine model for control analysis and design. SAE Paper 860455. http://www.sae.org/technical/papers/860455

Summers, M., 2007. ABB Turbochargers-history and milestones. ABB Rev., 2: 86-90.

Uchida, H., A. Kashimoto and Y. Iwakiri, 2006. Turbocharging Technologies Development of wide flow range compressor with variable inlet guide vane. R\&D Rev. Toyota CRDL, 41: 9-14.

Watson, N. and M. Marzouk, 1977. A non-Linear digital simulation of turbocharged diesel engines under transient conditions. SAE Paper 770123. http://www.sae.org/technical/papers/770123

Watson, N., 1981. Transient performance simulation and analysis of turbocharged diesel engines. SAE Paper 810338. http://www.sae.org/technical/papers/810338

Winterbone, D.E. and R. Backhouse, 1986. Dynamic behavior of a turbocharged diesel engine. SAE Paper 860453. 